Лєві Л. І., доктор технічних наук

Полтавський національний технічний університет імені Ю. Кондратюка

\title{
СИНТЕЗ АВТОМАТИЗОВАНОЇ СИСТЕМИ КЕРУВАННЯ ВОЛОГОЗАБЕЗПЕЧЕНІСТЮ СІЛЬСЬКОГОСПОДАРСЬКИХ КУЛЬТУР ПРИ ПІДІРУНТОВОМУ ЗВОЛОЖЕННІ
}

\section{Рецензент - доктор технічних наук О. В. Шефер}

Мета статmi - обтрунтувати ефективний підхід до синтезу структурної схеми каскаднокомбінованої автоматизованої системи керування вологозабезпеченістю модульної ділянки трунту за допомогою зміни рівня трунтових вод.

Методика дослідження. Включає моделі та методи системно-структурного аналізу та принциипи адаптивного керування складними технічними системами в умовах невизначеності.

Результати дослідження. Розроблено каскадно-комбіновану структурну схему автоматизованої системи керування вологозабезпеченістю сільськогосподарських культур при підтрунтовому зволоженні за допомогою зміни рівня трунтових вод. Показано, що така система має два контури регулювання: внутрішній контур регулювання рівня води у керуючому колодязі каскадно-комбінованої автоматизованої системи керування вологозабезпеченістю модульної ділянки трунту та зовнішній задаючий контур регулювання всмоктуючого тиску трунту, який характеризує вологість.

Елементи наукової новизни. Розроблено двоконтурну структурну схему автоматизованої системи керування вологозабезпеченістю сільськогосподарських культур при підтрунтовому зволоженні з урахуванням збурень.

Практична значущість. Дану розробку проведено для підвищення ефективності функиіонування автоматизованих систем керування вологозабезпеченістю сільськогосподарських культур при підтрунтовому зволоженні та забезпечення отримання гарантованих врожаӥв сільськогосподарських культур з одночасною економією водних та енергетичних ресурсів.

Ключові слова: каскадно-комбінована структурна схема, автоматизована система керування вологозабезпеченістю сільськогосподарських культур, внутрішній контур регулювання, зовнішній задаючий контур регулювання, впливи збурень на систему.

Лсві Леонід Ісаакович - доктор технічних наук, професор кафедри автоматики і електропривода, Полтавський національний технічний університет ім. Ю. Кондратюка, Першотравневий проспект, 24, м. Полтава, 36011, Україна, e-mail: levili@ukr.net.

Постановка проблеми. Проблема керування вологозабезпеченням сільськогосподарських культур у цілому світі є надзвичайно важливою. Перетворення сільськогосподарського виробництва у високорозвинутий сектор економіки неможливе без зменшення його залежності від несприятливих природо-кліматичних умов шляхом ведення зрошуваного землеробства у зонах недостатнього та нестійкого зволоження. Зрошуване землеробство $є$ важливою складовою виробництва продукції рослинництва, стабілізуючим фактором продовольчого та ресурсного забезпечення держави, особливо в роки 3 несприятливими погодними умовами.

Натепер технічний стан внутрішньогосподарських зрошувальних систем потребує покращення шляхом модернізації та докорінної реконструкції. Існуючі засоби водорегулювання потребують удосконалення в напрямі покращення точності регулювання рівнів води, врахування впливу випадкових зовнішніх збурень, забезпечення ресурсозберігаючих режимів зрошення сільськогосподарських рослин в умовах дефіциту водних та енергетичних ресурсів, що створить умови для ефективного ведення землеробства.

Аналіз останніх досліджень і публікацій, у яких започатковано розв'язання даної проблеми. Як відомо, максимальна врожайність сільськогосподарських культур досягається при оптимальній кількості вологи, живлення, тепла, повітря і світла. При цьому необхідний для сільськогосподарських культур водний режим грунту створюється відповідним режимом зрошення, який встановлює норми, терміни і кількості поливів залежно від біологічних особли- 


\section{ТЕХНІЧНІ НАУКИ}

востей культур, природних i господарських умов $[1,3]$. При визначенні витрат води на зрошення враховують водоспоживання, або сумарне випаровування, що залежить від кліматичних умов, кількості теплової енергії, яка надходить на поверхню, вологості грунту, виду та врожайності культури.

Питання управління водогосподарськомеліоративними об‘єктами у зоні надлишкового та нестійкого зволоження України на рівнях стратегічного та тактичного планування на основі поєднання короткотермінового та довготермінового метеорологічних прогнозів розглядалися у [4, 5, 8]. У [9] розроблено метод управління вологістю грунту на основі багатошарової моделі вологопереносу. Використання нечіткої логіки для автоматизації функціонування зрошувальних систем розглянуто в [6]. Застосування нейронних мереж для автоматизованого керування вологозабезпеченістю сільськогосподарських культур запропоновано в [7]. Однак залишаються невирішеними питання адаптації і самонавчання автоматизованих систем керування вологістю грунту в умовах дії випадкових погодних факторів, зміни характеристик об‘єкта керування, підвищення точності керування завдяки оперативному врахуванню дії збурень на об‘єкт, забезпечення отримання планової врожайності сільськогосподарських культур при раціональному використанні енергетичних і водних ресурсів. Крім того, сучасні системи керування вологозабезпеченістю сільськогосподарських культур повинні не тільки забезпечувати достатню точність керування, а й прогнозувати потребу рослин у воді на певний період, мінімізувати енергетичні та водні витрати без втрати врожаю, бути надійними та зручними в експлуатації, надавати оператору повну та своєчасну інформацію про значення усіх параметрів та стан системи керування. Комплексне вирішення цих проблем можливе лише за допомогою розробки сучасних технічних засобів автоматизації, нових математичних моделей вологопереносу у ненасиченій зоні грунту та методів керування вологозабезпеченістю сільськогосподарських культур. Отже, розробка методів автоматизованого керування вологозабезпеченістю сільськогосподарських культур з урахуванням збурень є актуальним науково-практичним завданням.

Метою роботи $\epsilon$ синтез структурної схеми каскадно-комбінованої автоматизованої системи керування (АСК) вологозабезпеченістю модульної ділянки грунту за допомогою зміни рівня грунтових вод (РГВ). Цю розробку проведено для підвищення ефективності функціонування таких систем та забезпечення отримання гарантованих врожаїв сільськогосподарських культур 3 одночасною економією водних та енергетичних ресурсів.

Для досягнення поставленої мети необхідно розв'язати наступні задачі:

1. Розробка внутрішнього контура регулювання рівня води у керуючому колодязі каскадно-комбінованої АСК вологозабезпеченістю модульної ділянки грунту.

2. Розробка зовнішнього задаючого контура регулювання всмоктуючого тиску грунту, який характеризує вологість.

3. Урахування впливів збурень на систему для підвищення точності регулювання і рівня ii технічної експлуатації.

Об'єктом дослідження $є$ процеси автоматизованого керування вологозабезпеченістю сільськогосподарських культур з підгрунтовим зволоженням.

Предметом дослідження $€$ системноструктурний аналіз АСК вологозабезпеченістю сільськогосподарських культур при підгрунтовому зволоженні з урахуванням діючих збурень.

Методи дослідження включають моделі та методи системно-структурного аналізу та адаптивного керування складними технічними системами в умовах невизначеності.

Результати дослідження. Структурну схему $[2,10]$ каскадно-комбінованої АСК вологозабезпеченістю модульної ділянки грунту за допомогою зміни РГВ наведено на рисунку.

На структурній схемі каскадно-комбінованої АСК вологозабезпеченістю модульної ділянки грунту за допомогою зміни РГВ застосовано такі позначення: W3 i W - заданий та виміряний всмоктуючі тиски відповідно; L3 і L - заданий та виміряний рівні води у керуючому колодязі відповідно; $\mathrm{EW}=\mathrm{W} 3-\mathrm{W} ; \mathrm{EL}=\mathrm{L} 3-\mathrm{L}-$ розузгодження; Lгр.в. - РГВ; PW - регулятор всмоктуючого тиску грунту; PL - регулятор рівня води у керуючому колодязі; ВМ - виконавчий механізм; РО - регулюючий орган. 


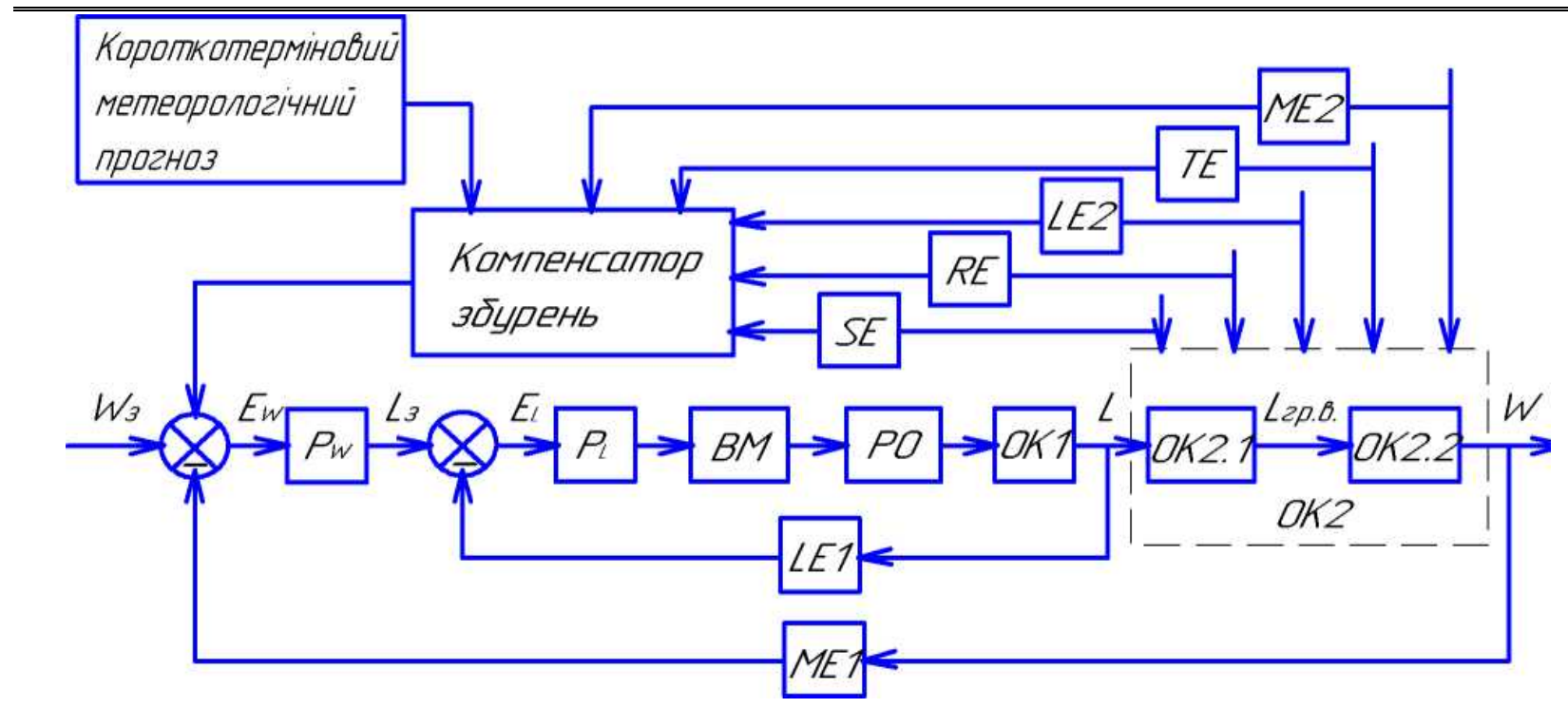

Рис. Структурна схема каскадно-комбінованої АСК вологозабезпеченістю модульної ділянки трунту за допомогою зміни РГВ

Джерело: власні дослідження.

Внутрішнім контуром регулювання є контур регулювання рівня води у керуючому колодязі (об“єкт керування ОК1), що вимірюється давачем LE1, а зовнішнім, задаючим, - контур регулювання всмоктуючого тиску грунту, який характеризує вологість. Об‘єкт керування ОК2 представляє собою ділянку грунту 3 колекторнодренажною системою. Він представлений на схемі у вигляді двох ланок. Перша ланка ОК2.1 відображає колекторно-дренажну систему та насичену зону грунту і перетворює рівень води у керуючому колодязі на напір у колекторнодренажній системі, а напір - на РГВ Lгр.в. Друга ланка ОК2.2 представляє собою ненасичену зону грунту і перетворює РГВ модульної ділянки на всмоктуючий тиск кореневмісного шару грунту $\mathrm{W}$, що вимірюється давачем ME1. На об‘єкт керування ОК2 діють наступні збурення: 1 - температура навколишнього середовища (ТЕ), 2 опади (LE2), 3 - освітленість (RE), 4 - швидкість вітру (SE), 5 - відносна вологість повітря (ME2), 6 - структура грунту, 7 - фаза розвитку рослини. Збурення 1-5 постійно змінюються в часі, а збурення 6 і 7 є сталими протягом достатньо великого проміжку часу. Крім того, величини збу-

\section{БІБЛІОГРАФІЯ}

1.Бочаров С. Ю. Автоматизация водорегулирующих комплексов. Ровно : Издательство РГТУ, 2000. $110 \mathrm{c}$.

2.Дорф P., Бишоп Р. Современные системы управления; пер. с англ. Б. И. Копылова. Москва: рень 1-5 можна передбачати 3 певною точністю на основі даних метеоспостережень.

Для підвищення точності регулювання і рівня технічної експлуатації зрошувальних систем необхідно враховувати вплив збурень на систему. Оскільки збурення весь час змінюються, АСК повинна оперативно розраховувати режим підгрунтового зволоження і реалізовувати його на керованих модулях зрошувальних систем 3 використанням технічних засобів водорегулювання.

Висновок. Розроблено каскадно-комбіновану структурну схему АСК вологозабезпеченістю сільськогосподарських культур при підгрунтовому зволоженні за допомогою зміни РГВ.

Показано, що така система має два контури регулювання: внутрішній контур регулювання рівня води у керуючому колодязі каскаднокомбінованої АСК вологозабезпеченістю модульної ділянки грунту та зовнішній задаючий контур регулювання всмоктуючого тиску грунту, який характеризує вологість.

Крім цього, передбачено врахування впливів збурень на систему для підвищення точності регулювання та рівня іiї технічної експлуатації.

Лаборатория Базовых знаний, 2004. 832 с.

3. Коваленко П. И. Автоматизация мелиоративных систем. Москва : Колос, $1983.304 \mathrm{c}$.

4. Коваленко П. И., Чальий Б. И., Тышенко А. И. Реконструкция мелиоративных систем. Київ : Урожай, 
1991. $168 \mathrm{c}$.

5. Ковальчук П. І. Моделювання і прогнозування стану навколишнього середовища. Київ : Либідь, 2003. $208 \mathrm{c}$.

6. Лєві Л. І. Використання нечіткої логіки для автоматизації функціонування зрошувальних систем. Вісник Полтавської державної аграрної академії. 2018. № 2. С. 153-157.

7.Лєві Л. І. Застосування нейронних мереж для автоматизованого керування вологозабезпеченістю сільськогосподарських культур. Вісник Полтавської державної аграрної академії. 2018. № 4. C. 201-204.

8. Науково-методичні та організаційні засади управління водогосподарсько-меліоративними

\section{REFERENCES}

1.Bocharov, S. Yu. (2000). Avtomatyzatsyia vodorehulyruiushchykh kompleksov [Automation of water-regulating complexes]. Rovno: Yzdatelstvo RHTU [In Russian].

2.Dorf, R., Byshop, R. (2004). Sovremennye systemy upravlenyia [Modern management systems]; per. s anhl. B.Y. Kopylova. Moskva: Laboratoryia Bazovykh znanyi [In Russian].

3. Kovalenko, P. Y. (1983). Avtomatyzatsyia melyoratyvnykh system [Automation of meliorative systems]. Moskva: Kolos [In Russian].

4. Kovalenko, P. Y., Chalyi, B. Y., Tyshenko, A. Y. (1991). Rekonstruktsyia melyoratyvnykh system [Reconstruction of reclamation systems]. Kyiv: Urozhai [In Russian].

5. Kovalchuk, P. I. (2003). Modeliuvannia $i$ prohnozuvannia stanu navkolyshnoho seredovyshcha [Modeling and forecasting the state of the environment]. Kyiv: Lybid [In Ukrainian].

6. Lievi, L. I. (2018). Vykorystannia nechitkoi lohiky dlia avtomatyzatsii funktsionuvannia zroshuvalnykh system [Use of fuzzy logic to automate the operation of irrigation systems]. Visnyk Poltavskoi derzhavnoi ahrarnoi akademii, 2, pp. 153-157 [In Ukrainian].

7. Lievi, L. I. (2018). Zastosuvannia neironnykh merezh dlia avtomatyzovanoho keruvannia volohozabezpechenistiu silskohospodarskykh kultur об’єктами гумідної зони України за короткотерміновим метеорологічним прогнозом. Методичні рекомендації / Рокочинський А. М., Зубик Я. Я., Зубик Л. В., Покладньов Є. І. ; за участю спеціалістів Держводгоспу України В. А. Сташук, В. Д. Крученюк. Рівне : НУВГП, 2005. $53 \mathrm{c}$.

9. Скрипник О.В. Системы двустороннего регулирования водного режима. Гидротехника $и$ мелиоращия. 1984. № 4. С. 55-57.

10.Юревич Е.И. Теория автоматического управления. 3-е изд. Санкт-Петербург : БХВПетербург, 2007. 560 с.

[Application of neural networks for automated control of moisture supply of agricultural crops]. Visnyk Poltavskoi derzhavnoi ahrarnoi akademii, 4, pp. 201-204 [In Ukrainian].

8. Rokochynskyi, A. M., Zubyk, Ya. Ya., Zubyk, L. V., Pokladnov, Ye. I. (2005). Naukovometodychni ta orhanizatsiini zasady upravlinnia vodohospodarsko-melioratyvnymy obiektamy humidnoi zony Ukrainy za korotkoterminovym meteorolohichnym prohnozom [Scientific, methodological and organizational principles of management of water management and reclamation facilities of the humane zone of Ukraine by shortterm meteorological forecast]. Metodychni rekomendatsii ; za uchastiu spetsialistiv Derzhvodhospu Ukrainy V. A. Stashuk, V. D. Krucheniuk. Rivne: NUVHP [In Ukrainian].

9. Skrypnyk, O. V. (1984). Systemy dvustoronneho rehulyrovanyia vodnoho rezhyma [Systems of bilateral regulation of water regime]. Hydrotekhnyka y melyoratsyia, 4, pp. 55-57 [In Russian].

10. Iurevych, E. Y. (2007). Teoryia avtomatycheskoho upravlenyia [The theory of automatic control. 3rd ed.]. 3-e yzd. SanktPeterburh: BKhV-Peterburh [In Russian].

Леви Л. И. Синтез автоматизированной системы управления влагообеспеченностью сельскохозяйственных культур при подпочвенном увлажнении

Цель статьи - обосновать эффективный подход к синтезу структурной схемы каскаднокомбинированной автоматизированной системы управления влагообеспеченностью модульного участка почвы с помощью изменения уровня грунтовых вод.

Методика исследования. Включает модели и методы системно-структурного анализа и приниипы адаптивного управления сложными техническими системами в условиях неопределенности. 


\section{ТЕХНІЧНІ НАУКИ}

Результаты исследования. Разработана каскадно-комбинированная структурная схема автоматизированной системь управления влагообеспеченностью сельскохозяйственньх культур при подпочвенном увлажнении с помощью изменения уровня грунтовых вод. Показано, что такая система имеет два контура регулирования: внутренний контур регулирования уровня воды в управляющем колодие каскадно-комбинированной автоматизированной системы управления влагообеспеченностью модульного участка почвы и внешний задающий контур регулирования всасывающего давления грунта, характеризующего влажность.

Элементы научной новизны. Разработана двухконтурная структурная схема автоматизированной системы управления влагообеспеченностью сельскохозяйственных культур при подпочвенном увлажнении с учетом возмущений.

Практическая значимость. Данную разработку проведено для повышения эффективности функиионирования автоматизированных систем управления влагообеспеченностью сельскохозяйственных культур при подпочвенном увлажнении и обеспечения получения гарантированных урожаев сельскохозяйственных культур с одновременной экономией водных и энергетических ресурсов.

Ключевые слова: каскадно-комбинированная структурная схема, автоматизированная система управления влагообеспеченностью сельскохозяйственных культур, внутренний контур регулирования, внешний задающий контур регулирования, влияние возмущений на систему.

Леви Леонид Исаакович - доктор технических наук, профессор кафедры автоматики и електропривода, Полтавский национальный технический университет им. Ю. Кондратюка, Первомайский проспект, 24, г. Полтава, 36011, Украина, e-mail: levili@ukr.net.

\section{Lievi L. I. The synthesis of automated control system of crops' water supply at subsoil moistening}

The purpose of the article is to substantiate the effective approach to the synthesis of the structural scheme of the cascade-combined automated system for controlling moisture supply of a module soil plot by changing the groundwater level.

Research methods include models and methods of systemic-structural analysis and the principles of adaptive regulation of complex technical systems under uncertain conditions.

The results of the research. The cascade-combined structural scheme of automated moisture regulation system for crops at subsoil moistening by changing the groundwater level has been developed. It has been shown that this system has two regulating circuits: the internal circuit for regulating water level in the master well of the cascade-combined automated moisture regulation system for a module plot of soil and the external setting circuit for regulating the suction pressure of the soil characterizing its humidity.

The elements of scientific novelty. A two-circuit structural scheme of automated control system for moisture supply of crops in case of subsoil moistening with perturbations has been developed.

Practical significance. This development was carried out to increase the efficiency of functioning automated systems for regulating moisture supply of crops during subsoil moistening and ensure the obtaining of guaranteed crop yields with simultaneous saving water and energy resources.

Key words: cascade-combined structural scheme, automated control system of moisture supply of crops, internal regulation circuit, external regulation driving circuit, perturbation effects on the system.

Lievi Leonid Isaakovych - Doctor of Technical Sciences, Professor, Poltava National Technical University named after Yuriy Kondratiuk, Department of Automation and Electric Drive, 24, Pershotravnevyi Av., Poltava, 36011, Ukraine, e-mail: levili@ukr.net.

Бібліографічний опис для цитування :

Стаття надійшла до редакції 21.02.2019 р.

Лєві Л. І. Синтез автоматизованої системи керування вологозабезпеченістю сільськогосподарських культур при підгрунтовому зволоженні. Вісник ПДАА. 2019. № 1. С. 227-231.

DOI 10.31210/visnyk2019.01.27

(С) Лєві Леонід Ісаакович, 2019 